Микола Саїнчук

кандидат наук з фізичного виховання та спорту,

Національний університет оборони України імені Івана Черняховського, м. Київ

ORCID ID: 0000-0002-7706-0242

Анна Саїнчук

кандидат наук з фізичного виховання та спорту,

Національний університет оборони України імені Івана Черняховського, м. Київ

ORCID ID: 0000-0002-3472-829X

Віктор Фідчунов

курсант IV курсу навчально-наукового інституту фізичної культури та спортивно-оздоровчих технологій

Національного університету оборони України імені Івана Черняховського, м. Київ

ORCID ID: 0000-0002-6751-1062

DOI: $10.33099 / 2617-1775 / 2021-01 / 314-321$

\title{
СПРИЙНЯТТЯ КУРСАНТАМИ МЕТЕОРОЛОГІЧНИХ ЧИННИКІВ ЯК БАР'СРУ ДЛЯ ЗАНЯТЬ ФІЗИЧНИМИ ВПРАВАМИ
}

Розглянуто психоемоційну чутливість та мотиваційні установки курсантів до занять фізичними вправами за різних метеорологічних умов. Проведено анкетуванням 3 курсантами чоловічої статі 1-4 курсів. Встановлено, щзо метеорологічна чутливість курсантів проявляється як на рівні фізіологічних реакиій, змінюючи роботоздатність, так $i$ в психологічному плані.

Ключові слова: курсанти, погода, фізичні навантаження, роботоздатність.

Постановка проблеми. Зовнішні чинники, особливо у видах рухової активності, що відбуваються на відкритому повітрі (сонячна радіація, рух повітря та його температура, опади, атмосферний тиск тощо), безпосередньо впливають на людину i, разом 3 цим, на іiі досягнення. Несприятливі навколишні умови вимагають від людського організму додаткової функціональної та психофізичної мобілізації сил для ефективної роботоздатності. Метеорологічні чинники часто розглядаються як бар'єр до занять фізичними вправами. Але цим можна виправдати хіба що власну лінь. Якщо підійти до несприятливих метеорологічних умов з установкою, що це чудовий засіб загартування, то цей бар'єр стає не настільки вагомим. Питання психоемоційних установок дуже суттєве i важливе. Тож, дослідження сприйняття курсантами фізкультурно-спортивного фаху (спеціалізації «Фізичне виховання і спорт у Збройних Силах») метеорологічних чинників як бар'єру для занять фізичними вправами є актуальною проблемою, адже це своєрідний індикатор їх установок та спроможностей долати постійно мінливі умови навколишнього середовища і налаштовувати в майбутньому своїх підопічних.

Аналіз останніх досліджень і публікацій. Фактори навколишнього середовища - мікроекологічні (прохідність, доступ до об'єктів та якість навколишнього середовища) [14] та макросередовище (погодні умови та 
температура повітря) [8-9] все частіше визначаються як потенційні детермінанти рухової активності [11], а не лише індивідуальні особливості, такі, як стать, вік та рівень освіти [10].

Несприятливі погодні умови зменшують фізичну працездатність залежно від їх інтенсивності, вихідного стану людини і важкості виконуваної роботи. Найбільше на неї впливає міждобовий градієнт температур, жорсткість та патогенність погоди. Вегетативний індекс відображає стан організму за некомфортних погодних умов і корелює із рівнем працездатності. Найбільш суттєву дію на нього чинить жорсткість погоди та мінливість температури. Даний індекс доцільно використовувати для самоконтролю стану для корекції фізичних навантажень з метою попередження травматизму та профзахворювань [2].

Зарубіжні дослідники зауважують, що сезонність та метеорологічні умови залишаються проігнорованими як визначальні фактори фізичної активності [13], а вони, між іншим, можуть сильно стимулювати або стримувати активну поведінку як літніх людей [12], так і молоді. Зокрема, дослідження показують, що рухова активність, середня й енергійна рухливість у підлітків чоловічої статі в основному змінюється під метеорологічними умовами у вільні дні, тоді як у дівчат підлітків зміни обумовлені тривалістю сонячного світла [7].

Рівень дозвіллєвої фізичної активності та фізичної підготовленості, як правило, вищий улітку, ніж у зимові місяці для більшості людей, що живуть подалі від екватора. Існують сезонні коливання у фізіологічних реакціях на фізичні вправи та травмування під час занять спортом [6]. Рівні фізичної активності змінюються залежно від сезону, а наслідки поганої або екстремальної погоди були визначені як перешкода для участі у фізичній активності серед різних груп населення [13].

Холодні та коротші дні мають суттєвий стримуючий вплив щодо рівня енергійності рухової активності під час занять фізичними вправами. При розробці заходів з підвищення рухової активності дорослих слід враховувати стратегії подолання екологічних бар'єрів [15].

Українські вчені досліджували дії несприятливих чи екстремальних погодних умов (дощу, снігу, високогір'я тощо) на результативність кваліфікованих спортсменів [1] та вплив погоди I-III типу на показники фізичної працездатності плавців та спортсменів гирьового спорту [3-5], але питання чутливості до метеорологічних змінних, психоемоційних установок на долання такого роду перешкод залишається не вивченим.

Мета дослідження - виявити чутливість курсантів до метеорологічних умов і їх вплив на результативність та бажання до занять фізичними вправами.

Виклад основного матеріалу дослідження. Людина як частина живої природи перебуває під безперервними впливами та взаємодіями біосфери Землі. Людина постійно адаптується до умов навколишнього середовища, iіi організм може бути більш або менш чутливим до різноманітних природних чинників, різним чином реагувати, але не попадати під вплив a priory не може. На людське бажання (мотивацію) займатися фізичними вправами може 
впливати багато чинників і суб’єктивне сприйняття зовнішніх метеорологічних умов часто залишаються поза увагою.

Для встановлення психоемоційної чутливості та мотиваційних установок курсантів до занять фізичними вправами за різних метеорологічних умов нами була розроблена анкета. Анкетуванням були охоплені курсанти чоловічої статі 1-4 курсів $(n=43)$ навчально-наукового інституту фізичної культури та спортивно-оздоровчих технологій Національного університету оборони України імені Івана Черняховського. Середній вік курсантів 1-го курсу - 17 років, 2-го курсу - 19 років, 3-го курсу - 20 років, 4-го курсу - 21 рік.

Опитування курсантів на предмет метеочутливості (табл. 1) показало, що не менше третини (40\% курсантів на 1-му курсі, 37,5\% - на 2-му, 38,5\% - на 3му і 33,3\% -на 4-му) зараховують себе до метеочутливих. Втім, переважаюча більшість метеочутливими себе не вважають, причому, чим старший курс, тим менше чутливих до погодних умов.

Уточнююче питання щодо перцепції якихось незвичних реакцій власного організму на звичайні фізичні навантаження але за несприятливих погодних умов показує, що більшість курсантів час від часу спостерігають за собою подібне (60\% курсантів першого курсу, 62,5\% - другого, 69\% - третього, 41,7\% - четвертого). Завжди відчувають - 20\% курсантів першого курсу, 7,7\% третього і 25\% - четвертого. Ніколи не відчували якихось незвичних реакцій на звичні навантаження за несприятливих природних умов 20\% курсантів першого курсу, 37,5\% - другого, 23\% - третього, 33,3\% - четвертого.

Аналіз питання анкети стосовно внутрішнього небажання, навіть, психологічного стресу від самої думки про майбутні фізичні навантаження в несприятливих метеорологічних умовах показав, що варіант відповіді "інколи" найрозповсюдженіший серед курсантів: на 1-му курсі таких 50\%, 2-му - 75\%, 3-му - 69,2\%, 4-му - 58,3\%. Ніколи погода не стає головним бар'єром щодо бажання/небажання займатися фізичними вправами для 40\% курсантів 1-го, $12,5 \%$ - другого, 15,4\% - третього та 41,7\% четвертого курсів. Несприятливі погодні умови завжди провокують внутрішнє небажання, психологічний стрес у 10\% курсантів першого, 12,5\% - другого, 7,7\% - третього курсу. Найстарший четвертий курс цей варіант відповіді взагалі не виділив.

Несприятливі погодні умови як чудовий засіб для загартовування організму та додатковий стимул до роботи сприймають найбільше на першому курсі - 90\%, на 2-му - всього 25\%, на 3-му - 38,5\%, а на 4-му - половина - 50\%. Реакцію у вигляді апатії та небажання спостерігають за собою 10\% курсантів першого курсу, 12,5\% - другого, 15,4\%, - третього і 16,6\% - четвертого. Ніколи в такому ключі не думали 37,5\% курсантів другого курсу, 46,1\% третього i $33,4 \%$ четвертого.

Дані анкетування в питанні мобілізації вольових зусиль при заняттях фізичним вихованням за несприятливих природних умов інформують, що більшості курсантів доводиться мобілізовувати вольові зусилля при практикуванні фізичних навантажень за несприятливих природних умов. Зокрема, завжди це роблять 50\% курсантів першого курсу, 37,5\% - другого, $38,4 \%$ - третього, 25\% - четвертого курсів; інколи мобілізують волю 50\% 
курсантів 1-го курсу, 37,5\% - 2-го, 38,4\% - 3-го і 25\% курсантів 4-го курсі. Ніколи не доводиться докладати вольових зусиль 15,3\% курсантам 3-го, 41,7\% курсантам четвертого курсу.

Таблицяя 1

\section{Сприйняття курсантами метеорологічних чинників як бар'єру для занять фізичними вправами, \%}

\begin{tabular}{|c|c|c|c|c|}
\hline Варіанти відповідей & $\begin{array}{l}1 \text { курс } \\
(\mathbf{n}=10)\end{array}$ & $\begin{array}{c}2 \text { курс } \\
(\mathbf{n}=8)\end{array}$ & $\begin{array}{l}3 \text { курс } \\
(n=13)\end{array}$ & 4 курс $(n=12)$ \\
\hline \multicolumn{5}{|c|}{ Чи вважаєте ви себе метеочутливим? } \\
\hline Так & 40 & 37,5 & 38,5 & 33,3 \\
\hline $\mathrm{Hi}$ & 60 & 62,5 & 61,5 & 66,7 \\
\hline \multicolumn{5}{|c|}{$\begin{array}{c}\text { Чи провокують у Вас небажання, психологічний стрес думки про майбутні фізичні навантаження в } \\
\text { несприятливих умовах навколишнього середовища? }\end{array}$} \\
\hline Завжди & 10 & 12,5 & 7,7 & 0 \\
\hline Ніколи & 40 & 12,5 & 15,4 & 41,7 \\
\hline Інколи & 50 & 75 & 69,2 & 58,3 \\
\hline Все залежить від характеру умов & 0 & 0 & 7.7 & 0 \\
\hline \multicolumn{5}{|c|}{$\begin{array}{c}\text { Чи сприймаєте Ви несприятливі погодні умови як чудовий засіб для загартовування Вашого } \\
\text { організму і чи це додатково стимулює Вас до роботи? }\end{array}$} \\
\hline Так, це додатково стимулює мене & 90 & 25 & 38,5 & 50 \\
\hline $\begin{array}{l}\text { Ні, це викликає в мене лише апатію і } \\
\text { посилює небажання }\end{array}$ & 10 & 12,5 & 15,4 & 16,6 \\
\hline Ніколи так не думав & 0 & 37,5 & 46,1 & 33,4 \\
\hline Власний варіант & 0 & 25 & 0 & 0 \\
\hline \multicolumn{5}{|c|}{$\begin{array}{c}\text { Чи задовольняс затверджена відповідно до умов форма одягу комфортним заняттям фізичними } \\
\text { вправами при несприятливих погодних умовах? }\end{array}$} \\
\hline $\begin{array}{l}\text { Форма одягу комфортна для занять } \\
\text { інтенсивним фізичним навантаженням у } \\
\text { несприятливі погодні умови }\end{array}$ & 50 & 37,5 & 23 & 25 \\
\hline $\begin{array}{l}\text { Форма одягу дискомфортна для занять } \\
\text { iнтенсивним фізичним навантаженням у } \\
\text { несприятливих погодних умовах }\end{array}$ & 50 & 62,5 & 77 & 75 \\
\hline \multicolumn{5}{|c|}{$\begin{array}{c}\text { Чи відчуваєте якісь незвичні реакції Власного організму на звичайні фізичні навантаження, але за } \\
\text { несприятливих погодних умовах? }\end{array}$} \\
\hline Так, завжди & 20 & 0 & 7,7 & 25 \\
\hline Ніколи & 20 & 37,5 & 23 & 33,3 \\
\hline Інколи & 60 & 62,5 & 69,2 & 41,7 \\
\hline \multicolumn{5}{|c|}{$\begin{array}{c}\text { Чи доводить мобілізувати вольові зусилля при практикуванні фізичних навантажень за } \\
\text { несприятливих природних умов? }\end{array}$} \\
\hline Так, завжди & 50 & 37,5 & 38,4 & 25 \\
\hline Ніколи & 0 & 0 & 15,3 & 41,7 \\
\hline Інколи & 50 & 62,5 & 46,1 & 33,3 \\
\hline \multicolumn{5}{|c|}{$\begin{array}{c}\text { Наскільки успішною є Ваша робото здатність при екстремальних(високих, низьких) } \\
\text { температурах? }\end{array}$} \\
\hline Стабільно висока роботоздатність & 30 & 37,5 & 30,7 & 58,3 \\
\hline Низька роботоздатність & 0 & 12,5 & 38,5 & 25 \\
\hline Звичайна роботоздатність & 70 & 37,5 & 30,8 & 16,7 \\
\hline Власний варіант & 0 & 12,5 & 0 & 0 \\
\hline
\end{tabular}

Оскільки курсанти зобов'язані носити відповідно сезону форму, в анкеті було питання щодо iї комфортності на заняттях фізичними вправами за несприятливих погодних умов. З'ясовано, що більшість курсантів вважають, що форма одягу дискомфортна для занять інтенсивним фізичним навантаженням у несприятливих погодних умовах (на першому курсі таких 50\%, на 2-му - 62,5\%, 
на 3-му - 77\%, на 4-му - 75\%). Комфортна форма одягу для 50\% курсантів першого курсу, $37,5 \%$ - другого, $23 \%$ - третього, $25 \%$ - четвертого.

Роботоздатність курсантів за екстремальних (високих, низьких) температур різна. Незалежно від температури звичайна роботоздатність у 70\% курсантів 1-го курсу, 37,5\% - 2-го курсу, 30,7\% - 3-го курсу й 16,7\% - 4-го курсу. Стабільно висока роботоздатність у 30\% курсантів 1-го курсу, 37,5\% - 2го курсу, 30,8\% 3-го курсу та 58,3\% курсантів 4-го курсу. Низьку роботоздатність помічають за собою 12,5\% курсантів 2-го курсу, 38,5\% 3-го і $25 \%$ четвертого курсу. Першокурсники цей варіант відповіді не виділили.

Виходячи з отриманих у ході опитування даних і фактів із літературних джерел, однозначно слід враховувати як метеорологічні умови, так i ix суб'єктивне сприйняття при плануванні різноманітних заходів рухової активності.

Висновки та перспективи подальших досліджень. Крім об'єктивних обставин, які передбачувано впливають на результативність фізичного виховання, не менш вартими уваги є суб'єктивні сприйняття і установки до занять фізичними вправами та долання навантажень за несприятливих метеорологічних умов. Більшість курсантів чутливі до метеорологічних умов не тільки на рівні фізіологічних реакцій (60\% курсантів першого курсу, 62,5\% другого, $69 \%$ - третього, $41,7 \%$ - четвертого час від часу спостерігають за собою незвичні реакції власного організму на звичайні фізичні навантаження) та змін роботоздатності (низька роботоздатність у 12,5\% курсантів 2-го курсу, 38,5\% 3го і 25\% четвертого курсу), але й у психологічному плані (внутрішне небажання, навіть психологічний стрес від самої думки про майбутні фізичні навантаження завжди є в 10\% курсантів 1-го курсу, 12,5\% - другого, 7,7\% третього курсу, а інколи - у 50\% першокурсників, 75\% - другокурсників, 69,2\% - третьокурсників і $58,3 \%$ - четвертокурсників; завжди доводиться мобілізувати вольові зусилля 50\% курсантів 1-го курсу, 37,5\% - 2-го, 38,4\% - 3го та $25 \%$ - 4-го).

Як засіб для загартовування організму та додатковий стимул до роботи несприятливі метеоумови розглядають 90\% першокурсників, на 2-му курсі таких всього $25 \%$, на 3 -му - 38,5\%, а на 4-му - половина (50\%). Тож, для більшості курсантів погодні умови $є$ бар'єром, який хотілося б уникнути, а не подолати.

\section{ЛІТЕРАТУРА}

1. Булатова М. М. Спортсмен у різних клімато-географічних та погодних умовах / М. М. Булатова, В. М. Платонов. - К.: Олімпійська література, 2000. - 176 с.

2. Васьковець Л.А. Вплив факторів навколишнього природного середовища на фізичну працездатність / Л.А. Васьковець, М.О. Глущенко // Восточно-Европейский журнал передовых технологий. - 2013. -3/11 (63) - С. 11-15.

3. Кульчицький 3.Й. Рівень фізичного стану спортсменів гирьового спорту за різних погодних умов / 3.Й. Кульчицький // Фізичне виховання студентів. - 2012. - № 1. - С. 56-58.

4. Курко Я. В. Плавання - засіб фізичної реабілітації у чутливих до змін погоди людей / Я.В. Курко // Педагогіка та медико-біологічні проблеми фізичного виховання $\mathrm{i}$ спорту. - 2011. - 12. - С. 54-57. 
5. Курко Я. В Особливості рівня фізичного стану спортсменів за різних погодних умов / Я.В. Курко, З.Й. Кульчицький // Педагогіка та медико-біологічні проблеми фізичного виховання і спорту. - 2011. - № 4. - С. 98-100.

6. Atkinson G., Drust B. Seasonal rhythms and exercise. Clin Sports Med. 2005 Apr;24(2):e25-34, xii-xiii. doi: 10.1016/j.csm.2004.11.001.

7. Beghin L., Vanhelst J., Drumez E., Migueles J., Manios Y., Moreno L.A., De Henauw S., Gottrand F. Influence of meteorological conditions on physical activity in adolescents. J Epidemiol Community Health. 2020 Apr; 74(4):395-400. doi: 10.1136/jech-2019-212459.

8. Bosdriesz J.R., Witvliet M.I., Visscher T.L.S., et al. The influence of the macroenvironment on physical activity: a multilevel analysis of 38 countries worldwide. Int $\mathbf{J}$ Behav Nutr Phys Activity 2012; 9: 110.

9. Chan C.B., Ryan D.A. Assessing the effects of weather conditions on physical activity participation using objective measures. Int j Environ Res Pub Health 2009; 6: 2639-54.

10. Gerovasili V., Agaku I.T., Vardavas C.I., et al. Levels of physical activity among adults 18-64 years old in 28 European countries. Prev Med 2015; 81:87-91.

11. Laverty A.A, Thompson H., Cetateanu A, Filippidis F.T. Macro-environmental factors and physical activity in 28 European Union countries, European Journal of Public Health, Volume 28, Issue 2, April 2018, Pages 300-302, doi.org/10.1093/eurpub/cky014

12. Merrill R.M., Shields E.C., White G.L., Druce D. Climate conditions and physical activity in the United States. Am J Health Behav 2005;29:371-81.

13. Tucker, T. and Gilliland, J. (2007) The Effect of Season and Weather on Physical Activity: A Systematic Review. Public Health, 121, 909-922.

14. Van Holle V., et al. Relationship between the physical environment and different domains of physical activity in European adults: a systematic review. BMC Public Health 2012; 12: 807.

15. Welch W.A., Spring B., Phillips S.M., Siddique J. Moderating Effects of WeatherRelated Factors on a Physical Activity Intervention. Am J Prev Med. 2018 May;54(5):e83-e89. doi: 10.1016/j.amepre.2018.01.025.

\section{REFERENCES}

1. Bulatova, M.M., Platonov, V.M. (2000). Sportsmen u riznykh klimato-heohrafichnykh ta pohodnykh umovakh [Athlete in different climatic, geographical and weather conditions]. Kyiv: Olimpiiska literature (in Ukrainian).

2. Vaskovets, L.A., Hlushchenko, M.O. (2013). Vplyv faktoriv navkolyshnoho pryrodnoho seredovyshcha na fizychnu pratsezdatnist [Influence of environmental factors on physical performance]. Vostochno-Evropeiskyi zhurnal peredovykh tekhnolohyi, 3/11, 11-15 (in Ukrainian)

3. Kulchytskyi, Z.I. (2012). Riven fizychnoho stanu sportsmeniv hyrovoho sportu za riznykh pohodnykh umov [The level of physical condition of weightlifters in different weather conditions]. Fizychne vykhovannia studentiv, 1, 56-58 (in Ukrainian).

4. Kurko, Ya. V. (2011). Plavannia - zasib fizychnoi reabilitatsii u chutlyvykh do zmin pohody liudei [Swimming is a means of physical rehabilitation for weather-sensitive people]. Pedahohika ta medyko-biolohichni problemy fizychnoho vykhovannia i sportu, 12, 54-57 (in Ukrainian).

5. Kurko, Ya. V., Kulchytskyi, Z.I. (2011). Osoblyvosti rivnia fizychnoho stanu sportsmeniv za riznykh pohodnykh umov [Features of the level of physical condition of athletes in different weather conditions]. Pedahohika ta medyko-biolohichni problemy fizychnoho vykhovannia i sportu, 4, 98-100 (in Ukrainian).

6. Atkinson, G., Drust, B. (2005). Seasonal rhythms and exercise. Clin Sports Med. Apr;24(2):e25-34, xii-xiii. doi: 10.1016/j.csm.2004.11.001. 
7. Beghin, L., Vanhelst, J., Drumez, E., Migueles, J., Manios, Y., Moreno, L.A., De Henauw, S., Gottrand, F. (2020). Influence of meteorological conditions on physical activity in adolescents. J Epidemiol Community Health. Apr; 74(4):395-400. doi: 10.1136/jech-2019-212459.

8. Bosdriesz, J.R., Witvliet, M.I., Visscher, T.L.S., et al. (2012). The influence of the macroenvironment on physical activity: a multilevel analysis of 38 countries worldwide. Int $\mathrm{J}$ Behav Nutr Phys Activity; 9: 110.

9. Chan C.B., Ryan D.A. (2009). Assessing the effects of weather conditions on physical activity participation using objective measures. Int j Environ Res Pub Health; 6: 2639-54.

10. Gerovasili V., Agaku I.T., Vardavas C.I., et al. (2015). Levels of physical activity among adults 18-64 years old in 28 European countries. Prev Med; 81:87-91.

11. Laverty A.A, Thompson H., Cetateanu A, Filippidis F.T. (2018). Macro-environmental factors and physical activity in 28 European Union countries, European Journal of Public Health, Volume 28, Issue 2, April, Pages 300-302, doi.org/10.1093/eurpub/cky014

12. Merrill R.M., Shields E.C., White G.L., Druce D. (2005). Climate conditions and physical activity in the United States. Am J Health Behav;29:371-81.

13. Tucker, T. and Gilliland, J. (2007). The Effect of Season and Weather on Physical Activity: A Systematic Review. Public Health, 121, 909-922.

14. Van Holle V., et al. (2012). Relationship between the physical environment and different domains of physical activity in European adults: a systematic review. BMC Public Health; 12: 807.

15. Welch W.A., Spring B., Phillips S.M., Siddique J. (2018). Moderating Effects of Weather-Related Factors on a Physical Activity Intervention. Am J Prev Med. May;54(5):e83-e89. doi: 10.1016/j.amepre.2018.01.025.

\section{РЕЗЮМЕ}

Николай Саинчук кандидат наук по физическому воспитанию и спорту, Национальный университет обороны Украины имени Ивана Черняховского., г. Киев ORCID ID: 0000-0002-7706-0242

Анна Саинчук кандидат наук по физическому воспитанию и спорту, Национальный университет обороны Украины имени Ивана Черняховского., г. Киев ORCID ID: 0000-0002-3472-829X

Виктор Фидчунов

курсант IV курса учебно-научного института физической культуры и спортивно-оздоровительных технологий

Национального университета обороны Украины имени Ивана Черняховского., г. Киев

\section{Восприятие курсантами метеорологических факторов как барьер к занятиям физическими упражнениями}

Рассмотрено психоэмоциональную чувствительность и мотивационные установки курсантов к занятиям физическими упражнениями при различных метеорологических условий. Проведено анкетирование с курсантами мужского пола 1-4 курсов. Установлено, что метеорологическая чувствительность курсантов проявляется как на уровне физиологических реакиий, изменяя работоспособность, так и в психологическом плане.

Ключевые слова: курсанты, погода, физические нагрузки, работоспособность. 
SUMMARY

MUMMARY
Mykola Sainchuk
Candidate of Sciences in Physical Education and Sports,
National Defense University of Ukraine
named after Ivan Chernyakhovsky, Kyiv
ORCID ID: 0000-0002-7706-0242
Anna Sainchuk
Candidate of Sciences in Physical Education and Sports,
University of Defense of Ukraine
named after Ivan Chernyakhovsky, Kyiv
ORCID ID: 0000-0002-3472-829X
Victor Fidchunov
cadet of the IV course of the educational and scientific institute
physical culture and sports and health technologies
National Defense University of Ukraine
named after Ivan Chernyakhovsky, Kyiv

\section{Perception by cadets of meteorological factors as a barrier to exercise}

Introduction. Adverse environmental conditions require from the human body additional functional and psychophysical mobilization of forces for effective performance. Meteorological factors often seen as a barrier to exercise. The issue of psycho-emotional attitudes is very significant and important.

Purpose. Identify the sensitivity of cadets to meteorological conditions and their impact on performance and desire to exercise.

Methods. We developed a questionnaire to establish the psycho-emotional sensitivity and motivational attitude of cadets to exercise in different weather conditions. Male cadets of 1-4 courses $(n=43)$ of the Educational and Scientific Institute of Physical Culture and Sports and Health Technologies of National Defense University of Ukraine named after Ivan Chernyakhovsky took part in the survey. The average age of 1 st year cadets are 17 years, 2nd year cadets are 19 years old, 3rd year cadets are 20 years old, and 4th year cadets are 21 years old.

Results. Most cadets are sensitive to meteorological conditions not only by physiological reactions (60\% of first-year cadets, $62.5 \%$ - second, $69 \%$ - third, $41.7 \%$ - fourth from time to time observe unusual reactions of their own body to normal physical load) and changes in workability (low workability in $12.5 \%$ of second-year cadets, $38.5 \%$ of $3 \mathrm{rd}$ and $25 \%$ of fourth-year students), but also psychologically (internal reluctance, even psychological stress from the very thought of the future physical activity is always present in $10 \%$ of first-year cadets, $12.5 \%$ - second-year, $7.7 \%$ third-year, and sometimes - 50\% of freshmen, $75 \%$ - sophomores, $69.2 \%$ - third-year students and $58,3 \%$ - fourth-year students, always have to mobilize the willpower of $50 \%$ of first-year cadets, $37.5 \%$ - 2nd, $38.4 \%$ - 3rd and $25 \%$ - 4th).

Conclusion. Based on the results of their own research and data from literature sources, when planning various activities of physical activity, it is necessary to take into account both meteorological conditions and their subjective perception.

Key words: cadets, weather, exercise, workability. 